В. Д. Лук'янчук

\title{
Фармакокінетичне дослідження процесів елімінації потенційного церебропротектора Цереброгерму в щурів 3 травмою головного мозку
}

\author{
Державна установа «Інститут фармакології та токсикології \\ Національної академії медичних наук України», м. Київ
}

Ключові слова: фармакокінетика, елімінація, координаційна сполука германію, церебропротектор,

черепно-мозкова травма

Неухильне збільшення питомої ваги черепно-мозкового травматизму (ЧМТ), значна інвалідизація та висока летальність потребують комплексного вивчення медико-соціальних аспектів даної проблеми [1-3]. За оцінками ВООЗ у країнах Європейського Союзу щороку відбувається близько 80 млн нещасних випадків, які в структурі причин смертності населення посідають місця після серцево-судинних та онкологічних захворювань, а за медико-соціальними збитками ЧМТ займає першу сходинку $[4,5]$. Тому проблема нейротравматизму є пріоритетною не тільки в Україні, але й у світі.

Лімітуючим чинником, що зменшує смертність від закритої черепно-мозкової травми (ЗЧМТ), є проведення раціональної фармакотерапії в ранньому посттравматичному періоді. Наразі фармакокорекція наслідків ЗЧМТ здійснюеться препаратами 3 різних фармакологічних груп, однак вони не відповідають у повному обсязі чинним вимогам щодо ефективності та безпечності.

3 огляду на вищевикладене, пошук i розробка нових церебропротекторів для усунення наслідків ЗЧМТ є актуальною проблемою сучасної фармакології.

у цьому плані увагу спеціалістів 3 кожним роком привертають оригінальні координаційні сполуки германію (КСГ) 3 різними біолігандами, які відрізняються широким спектром фармакодинамічних ефектів і нешкідливістю для теплокровних [6-8]. Разом з тим, питання фарма-

(с) Лук'янчук В. Д., 2020 кокінетики i, зокрема, елімінації потенційних церебропротекторів у ряду нових КСГ залишаються недостатньо вивченими. Раніше проведеними комплексними дослідженнями в нашій лабораторії було доведено високу цереброзахисну активність нової КСГ Цереброгерм [8, 9].

Мета дослідження - вивчити центральну ланку фармакокінетики Цереброгерму - елімінацію в нормі та за умов ЗЧМТ.

Матеріали та методи. Експериментальні дослідження виконані відповідно до «Загальних етичних принципів експериментів на тваринах" (Україна, 2001 р.), що узгоджуються з положеннями «Європейської конвенції про захист хребетних тварин, які використовуються для експериментальних та інших наукових цілей» (Страсбург, 1986 р.), а також згідно з методичними рекомендаціями ДП «Державний експертний центр МОЗ України» [10].

Досліди виконані на білих статевозрілих нелінійних щурах обох статей масою 170-240 г. В експерименті використовувалися тварини після проходження карантину, які отримували стандартну дієту у вигляді гранульованого корму за встановленими нормами, доступ до води був вільним.

Експериментальною моделлю ЗЧМТ був патологічний процес, що розвивається в тварин після нанесення дозованого за силою та орієнтованого за локалізацією удару вільно падаючим вантажем масою 45 г на тім'яну ділянку черепа щурів, що знаходилися під легким ефірним наркозом і були зафіксовані в удосконаленій камері Когана за допомогою спеціального пристрою 
оригінальної конструкції [11]. Клінічна картина форми ЗЧМТ, що моделюється, цілком відповідає механічному ушкодженню головного мозку середнього ступеня [12].

Цереброгерм (ферум біс(цитрато)германат) уперше синтезовано в лабораторії кафедри загальної хімії та полімерів Одеського національного університету імені I. I. Мечникова під керівництвом доктора хімічних наук, професора I. Й. Сейфулліної.

Комплексні дослідження фармакокінетичних параметрів Цереброгерму, що $\epsilon$ обов'язковим етапом доклінічного вивчення потенційних ліків, було проведено у повній відповідності до методичних рекомендацій ДП «Державний експертний центр МОЗ України» [13, 14] шляхом визначення концентрацій Цереброгерму за германієм у тканинах щурів без патології (норма) та в тварин, що отримували досліджувану координаційну сполуку 3 метою лікування патологічних змін, які формуються в ранньому посттравматичному періоді на тлі ЗЧМТ. Цереброгерм визначали в сироватці крові за раніше описаною в літературі методикою, що базується на екстракційно-фотометричному принципі визначення мікрокількостей германію [15]. Цереброгерм щурам водили в раніше розробленому режимі дозування: $126,5 \mathrm{мг/} \mathrm{кг} \mathrm{через} 70$ хв після початку моделювання ЗЧМТ.

Забір зразків біоматеріалу для визначення фармакокінетичного профілю Цереброгерму здійснювали в динаміці: через 30 хв, 2 год, 6 год, 12 год і 24 год 3 моменту одноразового внутрішньоочеревинного введення щурам ферум біс(цитрато)германату, тобто Цереброгерму. Визначали низку фармакокінетичних показників, що характеризують процеси елімінації, а саме: середній час перебування ксенобіотика в організмі (MRT, год), період напівелімінації $\left(\mathrm{t}_{1 / 2, \text { el }}\right)$, константа швидкості елімінації $\left(\kappa_{\mathrm{el}}\right)$, загальний кліренс $\left(\mathrm{Cl}_{\mathrm{T}}\right)$.

Параметри фармакокінетики Цереброгерму обчислювали за допомогою розроблених та затверджених Державним науково-експертним центром лікарських засобів МОЗ України комп'ютер- них програм у рамках одночасткової моделі зі всмоктуванням [16, 17].

Усі одиниці вимірів, кількісні показники та параметри наведені відповідно до Міжнародної системи одиниць [18]. Отримані результати дослідження обробляли статистично на персональному комп'ютері з використанням t-критерію Стьюдента [19]. Відмінності вважали вірогідними в разі значимості не менше ніж $95 \%$ за допомогою пакета прикладних програм Statistica 6.0.

Результати та їх обговорення. Наразі загальновідомо, що вельми важливим процесом, що відбувається з ксенобіотиками, у тому числі з ліками в організмі, є елімінація - заключний етап фармакокінетичних перетворень хімічних сполук та їнніх метаболітів, у результаті чого їхні активні форми повністю зникають з організму шляхом біотрансформації за рахунок екскреції або цих кінетичних процесів одночасно. Отримані в експерименті параметри, що характеризують процес елімінації Цереброгерму в здорових щурів та за умов ЗЧМТ, наведено в таблиці, 3 якої чітко видно, що період напівелімінації $\left(\mathrm{t}_{1 / 2}\right)$ координаційної сполуки, що досліджується, тобто час, за який з організму зникає половина введеної дози потенційного лікарського засобу, у тварин із патологією становить величину в 1,9 разу більшу, ніж у нормі. Іншими словами, концентрація сполуки в плазмі крові щурів дослідної групи підтримується значно більш тривалий час, упродовж якого відбувається реалізація фармакодинамічних ефектів Цереброгерму, спрямованих на церебропротекцію за умов ЗЧМТ.

Порівняльна оцінка константи швидкості елімінації $\left(\mathrm{K}_{\mathrm{el}}\right)$, яка характеризує швидкість зникнення координаційної сполуки германію 3 організму шляхом біотрансформації та екскреції й пов'язана зворотнопропорційною залежністю 3 величиною періоду напівелімінації, демонструє той факт, що цей процес у групі здорових тварин відбувається майже в 2 рази швидше, ніж у щурів 3 травматичною хворобою головного мозку.

Отримані в фармакокінетичному експерименті результати переконливо свідчать про уповільнення процесів елімінації Цереброгерму в ранньому посттравма- 
Таблиця

Фарлакокінетичні паралетри Цереброгерлу, що характеризують процес його елімінацї̈ в шурів за умов норми та закритої черепно-мозкової травли $(n=6)$

\begin{tabular}{|l|c|c|}
\hline \multirow{2}{*}{ Фармакокінетичний параметр } & \multicolumn{2}{c|}{ Група тварин } \\
\cline { 2 - 3 } & Норма & 3чмТ \\
\hline Період напівелімінації $\left(\mathrm{t}_{1 / 2}\right)$, год & $1,19 \pm 0,04$ & $2,24 \pm 0,08^{\star \star}$ \\
\hline Константа швидкості елімінації $\left(\mathrm{K}_{\mathrm{el}}\right)$, год ${ }^{-1}$ & $0,58 \pm 0,01$ & $0,31 \pm 0,01^{\star \star}$ \\
\hline Загальний кліренс $\left(\mathrm{Cl}_{\mathrm{T}}\right)$, мл/хв & $0,74 \pm 0,02$ & $0,38 \pm 0,01^{\star \star}$ \\
\hline Середній час перебування в організмі $(\mathrm{MRT})$, год & $24,20 \pm 1,07$ & $28,90 \pm 1,49^{\star}$ \\
\hline
\end{tabular}

Примітка. *p < 0,05 порівняно з нормою, **p <0,001 порівняно з нормою.

тичному періоді ЗЧМТ. Цей факт, як нам видається, пов'язаний з порушеннями, у першу чергу, процесів біотрансформації, а отже й детоксикаційних процесів у клітинах печінки та в організмі в цілому за умов ендотоксикозу внаслідок нейротравми, що моделюється.

Натепер є вже майже аксіомою той факт, що швидкість зникнення сполуки з організму характеризується також загальним (сироватковим) кліренсом, який надає додаткову інформацію щодо процесу елімінації й відповідає частині об’єму розподілу, що «очищується» від ксенобіотика за одиницю часу. Експериментально доведено, що значення загального кліренсу в тварин здорової та дослідної груп різняться майже в 2 рази в бік збільшення $\mathrm{Cl}_{\mathrm{T}}$ у тварин без патології (p < 0,001).

Досить повна фармакокінетична картина в частині елімінації Цереброгерму після його інтраперитонеального застосування отримана за таким кінетичним параметром, як середній час перебування в організмі.

Встановлено, що в тварин зі ЗЧМТ показник MRT на 20 \% вище порівняно 3 аналогічним у «нормі». Ці дані багато в чому природним чином співвідносяться з такими фармакокінетичними параметрами, як період напівелімінації та константа швидкості елімінації, що свідчить про менш інтенсивний плин реакцій біотрансформації та/або процесів екскреції за умов травматичної хвороби, що моделюється (таблиця).

Виявлена фармакокінетична модифікація всіх параметрів, що характеризують елімінацію потенційного церебропротектора на експериментальній моделі травматичної хвороби головно- го мозку, є, як нам видається, наслідком наступних обставин. 3 однієї сторони, враховуючи беззаперечну роль печінки та нирок у процесах екскреції ксенобіотиків, а 3 іншої - той факт, що в разі ЗЧМТ має місце формування синдрому ендогенної інтоксикації, за умов якої пошкоджується паренхіма нирок і гепатоцити, є підстави стверджувати, що елімінація Цереброгерму має відбуватися більш повільними темпами, що власне й спостерігається в експерименті.

\section{Висновок}

Таким чином, результати експерименту, що характеризують процеси елімінації координаційної сполуки германію - Цереброгерму, дозволяють заключити наступне: фармакокінетика цього потенційного церебропротектора суттєво змінюється залежно від умов їі дослідження, тобто в «нормі» чи за ЗЧМТ. Експериментально доведено, що за умов травматичної хвороби головного мозку відбувається пригнічення елімінаційних процесів за рахунок зменшення інтенсивності біотрансформації та ниркової екскреції. Це вказує на необхідність проведення додаткової фармакологічної підтримки метаболічно-екскреційних органів (печінка, нирки) у постраждалих із ЗЧМТ у ранньому посттравматичному періоді.

Щиро вдячний співробітникал кафедри загальної хілї̈ та полілерів Одеського національного університету

іл. I. I. Мечникова та особисто професору I. I. Сейфулліній

за синтез $і$ надану можливість вивчати низку нових координаційних сполук герланію. 
1. Клинико-эпидемиологические аспекты черепно-мозговой травмы (литературный обзор). Г. Ж. Аханов, Е. С. Утеулиев, Е. К. Дюсембеков и др. Вестник КазНМУ. 2018. № 3. С. 113-116.

2. Кондаков Е. Н., Кривецкий В. В. Черепно-мозговая травма: рук-во для врачей неспециализированных стационаров. Санкт-Петербург : СпецЛит, 2002. 271 с.

3. Салахов Э. Р., Какорина Е. П. Травмы и отравления в России и за рубежом. Проблемы социальной гигиены, здравоохранения и истории медицины. 2004. № 2. С. 13-20.

4. Хетагурова А. К., Галиулина О. В. Медико-социальные аспекты травматизма в Тюменской области: современные подходы к совершенствованию травматологической помощи. Сестринское дело. 2008. № 8. С. 14-18.

5. Социальные и эпидемиологические аспекты черепно-мозговой травмы (обзор). Д. М. Овсянников, А. А. Чехонацкий, В.Н.Колесов, А. И. Бубашвили. Саратовский научно-медицинский журнал. 2012. Т. 8, № 3. С. 777-785.

6. Координаційні сполуки германію - потенційні засоби знешкодження при ендотоксикозі. В. Й. Кресюн, Т. Р. Лучишин, І. Й. Сейфулліна та ін. Журнал АМН України. 2012. Т. 18, № 1. С. 120-125.

7. Скринінг і порівняльна оцінка протиішемічної ефективності серед координаційних сполук германію при гострій церебро-васкулярній недостатності. В. Д. Лук'янчук, І. О. Житіна, І. Й. Сейфулліна та ін. Фармакологія та лікарська токсикологія. 2010. № 1-2 (14-15). С. 61-64.

8. Поліщук Є. М. Експериментальне обґрунтування доцільності застосування координаційної сполуки цереброгерм для лікування травматичного пошкодження головного мозку: автореф. дис. на здобуття наукового ступеня канд. мед. наук : 14.04.05 - фармакологія. Одеса, 2016. 20 с.; укр.

9. Порівняльна оцінка церебропротекторної активності вперше синтезованих координаційних сполук біс(цитрато)германатів(станатів) на скринінговій моделі закритої черепно-мозкової травми. В. Д. Лук'янчук, Є. М. Поліщук, І. Й. Сейфулліна та ін. Фармакологія та лікарська токсикологія. 2014. № 2 (38). С. 36-43.

10. Доклинические исследования лекарственных средств : метод. рекоменд.; под ред. чл.-корр. АМН Украины А. В. Стефанова. Киев : ВД «Авіцена», 2002. 567 с.

11. Патент на корисну модель 13678, Україна, МПК G09B 23/28. Спосіб моделювання черепномозкової травми. В. Д. Лук'янчук, О.В.Шевчук, О. В. Бадінов. № и 2005 09483; Заявл. 10.10.05; Опубл. 17.04.06, Бюл. № 4. 8 с.

12. Травматология: национальное руководство; под ред. Г. П. Котельникова, С. П. Миронова. Москва : ГЭОТАР-Медиа, 2008. 808 с. (Серия «Национальные руководства»).

13. Доклиническое изучение фармакокинетики лекарственных средств; под ред. проф. В. С. Даниленко. Доклинические исследования лекарственных средств : метод рекомендации. Киев : ГФЦ МЗ Украины, 2002. С. 548-559.

14. Методичні рекомендації по доклінічному вивченню фамакокінетики лікарських засобів. М. Я. Головенко, І. С. Безверха, В. А. Жила та ін. Київ : Фармакологічний комітет МОЗ України, 1995. 27 c.

15. Кресюн В. Й., А. Г. Відавська, К. Ф. Шемонаєва. Екстракційно-фотометричне визначення мікрокількостей германію у тканинах експериментальних тварин. Одеський медичний журнал. 2000. № 6 (62). С. 7-11.

16. Кравец Д. С. Расчет фармакокинетических параметров ксенобиотиков с помощью пЭВМ. V Національний з'їзд фармацевтів України «Досягнення сучасної фармації та перспективи ії розвитку у новому тисячолітті»: тези доп. Харків, 1999. С. 679-680.

17. Методические рекомендации по компьютерным расчетам фармакокинетических параметров лекарственных средств (линейные частевые модели). Н. Я. Головенко, В. Д. Лукьянчук, О. В. Жук и др. Киев : Государственный научно-экспертный центр лекарственных средств, 1999. 70 с.

18. Липперт Г. Международная система единиц (СИ) в медицине. Москва : Медицина, 1980. 208 с.

19. Петри А., Сэбин К. Наглядная статистика в медицине; пер. с англ. Москва : ГЭОТАР-Медиа, 2003. $143 \mathrm{c}$.

20. Гланц С. Медико-биологическая статистика; пер с англ. Моска : Практика, 1999. 459 с.

\section{В. Д. Лук'янчук \\ Фармакокінетичне дослідження процесів елімінації потенційного церебропротектора Цереброгерму в щурів з травмою головного мозку}

Роботу присвячено фармакокінетичному дослідженню процесів елімінації нової координаційної сполуки германію - Цереброгерму (ферум біс(цитрато)германат), який проявляє виразну церебропротекторну активність на моделі закритої черепно-мозкової травми (ЗЧМТ).

Модель ЗЧМТ відтворювали в щурів шляхом нанесення дозованого за силою та орієнтованого за локалізацією удару вільно падаючим предметом масою 45 г на тім'яну ділянку черепа щурів у стані легкого ефірного наркозу. Форма ЗЧМТ, що моделюється, відповідає травмі головного мозку середнього ступеня. 
Досліджували низку параметрів, що характеризують процес елімінації: період напівелімінації $\left(\mathrm{t}_{1 / 2, \mathrm{e}}\right.$, год), константа швидкості елімінації $\left(\mathrm{K}_{\mathrm{el}}\right.$, год $\left.{ }^{-1}\right)$, загальний кліренс $\left(\mathrm{Cl}_{\mathrm{T}}, \mathrm{M} / \mathrm{xв}\right)$, середній час перебування в організмі (MRT, год) у щурів з зЧМТ порівняно зі здоровими тваринами (норма). Порівняльний аналіз отриманих фармакокінетичних параметрів Цереброгерму, що характеризують процес його елімінації в щурів у нормі та за умов ЗЧМТ, переконливо ( $<<0,050-0,001)$ свідчить про уповільнення процесів біотрансформації та екскреції потенційного церебропротектора в ранньому посттравматичному періоді. Найбільше за умов ЗЧМТ змінюються період напівелімінації, константа швидкості елімінації, загальний кліренс.

У роботі обговорюються причини змін параметрів, що характеризують елімінацію потенційного церебропротектора на експериментальній моделі травматичної хвороби головного мозку.

Отримані дані можуть бути експериментальним обґрунтуванням необхідності проведення додаткової фармакологічної підтримки метаболічно-екскреційних органів (печінка, нирки), що буде сприяти підвищенню ефективності фармакотерапії наслідків ЗЧМТ у ранньому посттравматичному періоді.

Ключові слова: фармакокінетика, елімінація, координаційна сполука германію, церебропротектор, черепно-мозкова травма

\section{В. Д. Лукьянчук \\ Фармакокинетическое исследование процессов элиминации потенциального церебропротектора Цереброгерма у крыс с травмой головного мозга}

Работа посвящена фармакокинетическому исследованию процессов элиминации нового координационного соединения германия - Цереброгерма (феррумбис(цитрато)германат), который проявляет выраженную церебропротекторную активность на модели закрытой черепно-мозговой травмы (ЗЧМТ).

Опыты выполнены на модели ЗЧМТ, воспроизводимой у крыс путем нанесения дозированного по силе и ориентированного по локализации удара свободно падающим предметом массой 45 г на теменной участок черепа крыс в состоянии легкого эфирного наркоза. Форма ЗЧМТ, которая моделируется, соответствует травме головного мозга средней степени.

Исследование ряда параметров, характеризующих процесс элиминации: период полувыведения $\left(\mathrm{t}_{1 / 2, \text { el }}, 4\right)$, константа скорости элиминации $\left(\mathrm{K}_{\mathrm{el}}, \mathrm{4}^{-1}\right)$, общий клиренс $\left(\mathrm{Cl}_{\mathrm{T}} \mathrm{M} / \mathrm{Mnн}\right)$, среднее время пребывания в организме (MRT, ч) у крыс с ЗЧМТ проведены по сравнению со здоровыми животными (норма). Сравнительный анализ фармакокинетических параметров Цереброгерма, характеризующих процесс его элиминации у крыс в норме и в условиях ЗЧМТ, убедительно ( $<<0,05-0,001)$ свидетельствует о замедлении процессов биотрансформации и экскреции потенциального церебропротектора в раннем посттравматическом периоде ЗЧМТ. Наиболее изменяются при ЗЧМТ период полувыведения, константа скорости элиминации, общий клиренс.

В работе обсуждаются причины изменений параметров, характеризующих элиминацию потенциального церебропротектора на экспериментальной модели травматической болезни головного мозга.

Полученные данные могут служить экспериментальным обоснованием необходимости проведения дополнительной фармакологической поддержки метаболически - экскреционных органов (печень, почки), что будет способствовать повышению эффективности фармакотерапии последствий ЗЧМТ у пострадавших в раннем посттравматическом периоде.

Ключевые слова: фармакокинетика, элиминация, координационное соединение германия, церебропротектор, черепно-мозговая травма

\section{D. Lukyanchuk \\ Pharmacokinetic study of elimination processes of potential cerebroprotector Cerebrogerm in rats with isolated craniocerebral trauma}

This work is dedicated to pharmacokinetic studies of elimination processes of new coordination germanium compound Cerebrogerm (ferum bis(cytrato)germanate), which shows pronounced cerebroprotective activity on the model of isolated craniocerebral trauma (ICT).

Experiments were conducted on ICT model, which was recreated in rats by application of a strike dosed by strength and oriented by localization with a falling $45 \mathrm{~g}$ object on parietal skull part of rats under light ether anesthesia. ICT, which is being modeled, matches moderate form of brain injury.

There were studied variety of parameters, which characterize elimination process: period of half elimination $\left(\mathrm{t}_{1 / 2, \mathrm{e}}\right.$, hour), elimination rate constant $\left(\mathrm{K}_{\mathrm{el}}\right.$, hour $\left.{ }^{-1}\right)$, general clearance $\left(\mathrm{Cl}_{\mathrm{T}}, \mathrm{ml} / \mathrm{min}\right)$, average residence time in organism (MRT, hour) in rats with ICT in comparison to healthy animals (norm). Comparative analysis of obtained pharmacokinetic parameters of Cerebrogerm, which characterize the process of it's elimination in normal and ICT condition rats convincingly $(p<0,050-0,001)$ indicates deceleration of processes of biotransformation and excretions of potential cerebroprotector in early stages of post traumatic period of ICT.

Most intensive changes occur in period of half elimination, elimination rate constant and general clearance. 
Reasons of changes of parameters, which characterize elimination of potential cerebroprotector on experimental models of traumatic brain disorder, are discussed.

The data obtained can be an experimental basis for necessity of additional pharmacological support of metabolic-excretion organs (kidneys, liver) which will contribute to increase in effectiveness of pharmacotherapy of consequences of ICT in early post traumatic period.

Key words: pharmacokinetics, elimination, coordination germanium compound, cerebroprotector, craniocerebral trauma

Надійшла: 27 травня 2020 р.

Прийнята до друку: 9 липня 2020 р.

Контактна особа: Лук'янчук Віктор Дмитрович, доктор медичних наук, професор, головний науковий співробітник, відділ медичної хімії, ДУ«Інститут фармакології та токсикології НАМН України», буд. 14, вул. Антона Цедіка, м. Київ. Тел.: + 380501689707. 